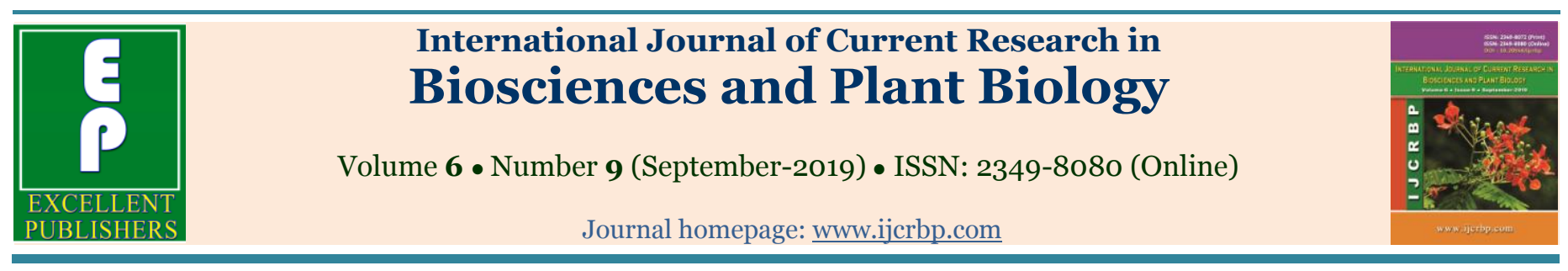

\title{
Phenotypic and genotypic variability, heritability and correlation estimates for agro-morphological characteristics of eggplant (Solanum melongena) in Côte d'Ivoire
}

\author{
KOUASSI Abou Bakari*, KOUASSI Koffi Brice Aymar, ALLA N'NAN Oulo, \\ KOUASSI Auguste and N'GUETTA Assanvo Simon-Pierre
}

Laboratoire de génétique, UFR-Biosciences, Université Félix Houphouët-Boigny (UFHB), 22 BP 582 Abidjan 22

*Corresponding author; e-mail: abou_kouassi@yahoo.fr; Phone: (+225) 49025665 /o1349240

\begin{tabular}{|c|c|}
\hline Article Info & ABSTRACT \\
\hline $\begin{array}{l}\text { Date of Acceptance: } \\
28 \text { August } 2019\end{array}$ & \multirow{3}{*}{$\begin{array}{l}\text { Estimates of genetic parameters of agro-morphological characteristics are essential for } \\
\text { the genetic improvement of crop plants. The purpose of this study was to estimate the } \\
\text { variance components, the heritability, genotypic and phenotypic coefficients of } \\
\text { variation as well as genetic and phenotypic correlation coefficients of different agro- } \\
\text { morphological traits in eggplant, Solanum melongena. The plant material was } \\
\text { composed of: a) } 8 \text { accessions of } S \text {. melongena, b) } 8 \text { accessions of } 6 \text { wild relatives and c) } \\
36 \text { interspecific F1 hybrid progenies. Fifteen agro-morphological traits were measured } \\
\text { on five plants of each parental accession and each F1 progeny, arranged in the fields in a } \\
\text { randomized complete block design. For all the traits studied, phenotypic coefficients of } \\
\text { variation were higher than genotypic coefficients of variation. However, the gaps } \\
\text { between these phenotypic and genotypic coefficients of variation were small, indicating } \\
\text { a weak influence of the environment on the traits. Values of the narrow sense } \\
\text { heritability were high and suggest strong contributions of genes with additive effects in } \\
\text { the expression of the traits. Genotypic and phenotypic correlation coefficients between } \\
\text { vegetative growth characteristics and fruit characteristics were low to moderate. } \\
\text { Selection pressures can therefore be applied to yield related traits without significantly } \\
\text { affecting vegetative growth traits, and vice versa. These estimates of the genetic } \\
\text { parameters show that genetic improvement of eggplant can be achieved effectively by } \\
\text { mass selection on the basis of phenotypic values of agro-morphological characteristics. }\end{array}$} \\
\hline Keywords & \\
\hline $\begin{array}{l}\text { Coefficient of variation } \\
\text { Coefficient of correlation } \\
\text { Eggplant } \\
\text { Heritability } \\
\text { Selection pressure }\end{array}$ & \\
\hline
\end{tabular}

\section{Introduction}

Eggplant, Solanum melongena, is an important vegetable crop in the tropical and subtropical regions of the world. This species is related to a large number of species belonging to the subgenus Leptostemonum of the Solanaceae family (Daunay and Hazra 2012; Vorontsova et al., 2013). Like many crop plant, eggplant has a narrow genetic base that makes it susceptible to many biotic and abiotic stresses (Muñoz-Falcón et al., 2009; Meyer et al., 2012; Hurtado et al., 2015). Wild relatives of S. melongena can be found in a much wider range of environmental conditions. They have a greater allelic diversity and could therefore play a major role in the improvement of eggplant. The aim of this improvement would be to increase the genetic base of eggplant and its adaptation to various 
environments, in particular to changing environmental conditions due to the effects of climate change.

Sexual hybridization of $S$. melongena and wild relatives have resulted in novel genotypes with introgressions of genes of wild relatives in the genome of $S$. melongena (Plazas et al., 2016; Kouassi et al., 2016, Gramazio et al., 2017). These genotypes can be characterized based on phenotypic traits. Then, best genotypes responding to the challenges of modern agriculture and the needs of farmers and consumers can be selected based on the estimates of genetic parameters such as genotypic and phenotypic coefficients of variation, genotypic and phenotypic coefficients of correlation and heritability. Indeed, genetic advance in a plant breeding program depends on the variability in the genetic resources (populations of collected varieties and wild relatives) of the targeted crop species (Fasoula and Fasoula, 2002). So, estimates of the morphogenetic variability of difference accessions of eggplant and wild relatives can provide an insight on their usefulness in breeding programs. On the other hand, for many crop plants, various traits of agronomic interest such as vegetative growth and production traits are highly dependent on environmental factors and generally have a polygenic determinism (Rajib et al., 2011).

Estimates of variance components and the heritability of the traits of interest are therefore useful for the prediction of their transmissibility from parental accessions to their progenies. Also, since many traits need to be improved simultaneously, it is important to know their genetic and phenotypic correlation coefficients in order to appreciate the putative effect(s) on the other traits if a selection pressure is applied to one particular trait.

Estimates of genetic parameters have already been reported for some accessions of eggplant and related cultivated species. For instance, genetic variability, correlations, level of heritability and genetic advance have been determined for yield related traits of Solanum anguivi (Denton and Nwangburuka, 2011) and eggplant (Patel et al., 2017, Verma et al., 2018; Nand et al., 2018; Tirkey et al., 2018; Divya and Sharma, 2019). Similar data have been obtained for agronomic interest traits for selection of garden eggplant, Solanum gilo Raddi (Danquah and Ofori, 2012), African eggplant, S. aethiopicum (Sawadogo et al., 2016) and eggplant, $S$. melongena (Akpan et al., 2016; Yadav et al., 2016; Jirankali et al., 2019). All these studies were undertaken with different sets of accessions without any genealogical relationship. Nevertheless, as argued by Hodge et al. (1996), the use of this type of plant material may lead to biased estimates of genetic parameters. In contrast, more reliable genetic parameters can be obtained by estimating variances components based on the genetic relationship matrix in the plant material (Kruuk, 2004; Kouassi et al., 2009). This approach relies on the use of a mixed model combining the "animal genetic model" with residual maximum likelihood (REML) techniques (Thompson, 2008).

So far, genetic parameters of agro-morphological traits have not yet been estimated for eggplant in agroclimatic conditions of Côte d'Ivoire. The objective of this study is thus to use a pedigreebased approach to estimate variance components and genetic parameters of different agromorphological traits of eggplant in Côte d'Ivoire for their effective use in oncoming breeding programs.

\section{Materials and methods}

\section{Plant material}

The plant material consisted of: a) 8 accessions of $S$. melongena originating from Ivory Coast (M1, M2 and M3) and Sri Lanka (M4, M5, M6, M7 and M9). These accessions are representative of the genetic diversity of $S$. melongena. Indeed, the 3 accessions from Côte d'Ivoire belong to the "western" genetic group while the 5 accessions from Sri Lanka belong to the "eastern" genetic group (Vilanova et al., 2012; Cericola et al., 2013). (b) 8 accessions of 6 eggplant wild relatives belonging to the primary and secondary gene pools. They are: 2 accessions of $S$. insanum (IS1 and IS3); 1 accession of $S$. aethiopicum, (AT1), 2 accessions of $S$. anguivi (AG1 and AG2), 1 accession of $S$. dasyphyllum (DS1), 1 accession of $S$. linneanum (LN1), 1 accession of $S$. tomentosum (TM1). c) 36 interspecific F1 hybrid progenies between the six accessions of $S$. melongena and the 8 accessions of wild relatives (Table 1 ). 


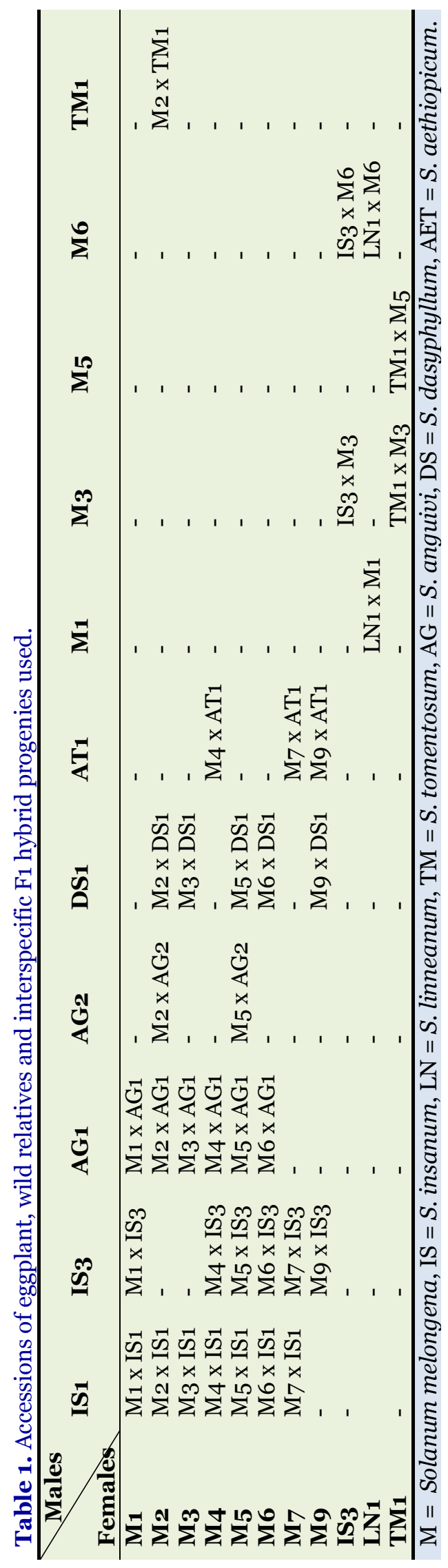

\section{Methods \\ Experimental design and plants growing conditions}

The study was carried out in 2016 in an experimental plot of the National Center for Agronomic Research (CNRA) of Côte d'Ivoire, located at latitude $5^{\circ} 19^{\prime} 516^{\prime \prime}$ North, longitude $004^{\circ}$ o8' 206' West and $37 \mathrm{~m}$ above sea level. Seedlings of parental accessions and F1 hybrid progenies were transplanted onto the field during the great rainy season (April to July) in a randomized complete block design. The plants were spaced by 1.5 and $1 \mathrm{~m}$, respectively between and within rows. When pest attacks were observed, the fungicide "Ivory 80 WP" (Composition: Mancozeb $80 \mathrm{~g} / \mathrm{kg}$ ) and the insecticide "Cypercal 50 EC" (composition: Cypermethrin $50 \mathrm{~g} / \mathrm{L}$ ) were applied at the rates of $2 \mathrm{~kg} /$ ha and $1 \mathrm{~L} / \mathrm{ha}$, respectively. Fertilization was carried out with a composite fertilizer $\mathrm{N}: \mathrm{P}: \mathrm{K}(12: 22: 22)$ at a rate of 25 $\mathrm{g}$ per plant per month. At the flowering stage, pollination was carried out manually, using mainly accessions of $S$. melongena as female parents. They were used as male parents only in cases where it was difficult to obtain fruits by using them as female parents.

\section{Data collection}

Fifteen agromorphological traits including 7 vegetative growth characteristics and 8 yield related traits (Table 2), identified from the eggplant descriptor (IBPGR, 1990), were measured on parental accessions and their interspecific $\mathrm{F} 1$ hybrid progenies. Vegetative growth characteristics were scored when the first flowers were observed. Characteristics of flowers were collected on 3 to 4 randomly selected inflorescences per plant. When the inflorescence consists of more than 3 flowers, the stamens were counted on 3 flowers also randomly selected. Fruit characteristics were measured on 3 to 4 fruits per plant.

\section{Data analysis}

Estimates of variance components were obtained using a mixed linear model based on the Restricted Maximum Likelihood (REML) method (Patterson and Thompson, 1971). The mathematical model 
applied to all the characters has the following matrix notation: $\mathrm{Y}=\mathrm{X} \beta+\mathrm{Z} \alpha+\boldsymbol{e}$. Where: $\mathrm{Y}$ is the vector of the phenotypic values in the population, $X$ is the fixed effects incidence matrix, $\beta$ is the vector of fixed effect, $Z$ is the random effects incidence matrix, $\alpha$ is the vector of random effects (additive genetic effects) and $\boldsymbol{e}$ is the vector of residual effects, that is, other effects such as dominance, epistasis and non-genetic effects (Kruuk, 2004; Mrode, 2005).

Table 2. Phenotypic descriptors used for agro-morphological characterization of parental accessions and interspecific hybrid progenies.

\begin{tabular}{lllll}
\hline $\mathbf{N}^{\mathbf{0}}$ & Descriptor & Unity (IS) & Code & Type of descriptor \\
\hline 1 & Plant Height & $\mathrm{cm}$ & PLHE & \\
2 & Plant Canopy Width & $\mathrm{cm}$ & PLWI & \\
3 & Ramification Index & - & RAM & \\
4 & Leaf Blade Length & $\mathrm{cm}$ & LBLE & Vegetative Growth traits \\
5 & Leaf Blade Width & $\mathrm{cm}$ & LBWI & \\
6 & Petiole Length & $\mathrm{cm}$ & PELE & \\
7 & Petiole Diameter & $\mathrm{mm}$ & PEDI & \\
\hline 8 & Number of Flowers/Inflorescence & - & NFLIN & \\
9 & Number of stamens & - & NBST & \\
10 & Fruit Length & $\mathrm{cm}$ & FRLE & \\
11 & Fruit Width & $\mathrm{cm}$ & FRWI & Yield related traits \\
12 & Fruit Pedicel Length & $\mathrm{cm}$ & FRPL & \\
13 & Fruit Pedicel Diameter & $\mathrm{mm}$ & FRPD & \\
14 & Number of Fruits/Infructescence & - & NFRIN & \\
15 & Fruit Weight & $\mathrm{g}$ & FRWE & \\
\hline IS: Inteith & & &
\end{tabular}

IS: International System.

Matrices of variances/covariances as well as matrices of genotypic and phenotypic correlation coefficients were obtained using the Variance Components Estimation (VCE) package, version 6.0.2 (Groeneveld et al., 2010). The different matrices provided by the VCE 6.0.2 package were used to calculate the narrow-sense heritability $\left(\mathrm{h}^{2}\right)$ as well as the phenotypic (PCV) and genotypic (GCV) coefficients of variation. GCV and PCV were considered low when the values are below 11\%, moderate between 11 and 20\% and high for values above 20\% (Sumathi et al., 2010). Additive genotypic correlation $\left(\mathrm{r}_{\mathrm{a}}\right)$ and phenotypic correlation $\left(r_{p}\right)$ coefficients were also computed with the VCE 6.0.2 package. The genetic parameters were calculated according to the following formulas:

$$
\begin{aligned}
& \mathbf{h}^{2}=\frac{\sigma_{\mathrm{a}}^{2}}{\sigma_{\mathrm{p}}^{2}}, \mathbf{P C V}=\left(\frac{\sqrt{\sigma^{2} \mathrm{p}}}{\mu}\right) \times 100, \mathbf{G C V}=\left(\frac{\sqrt{\sigma^{2} \mathrm{a}}}{\mu}\right) \times 100 \\
& \text { and } \mathbf{r}=\frac{\operatorname{cov}(\mathrm{x}, \mathrm{y})}{\sqrt{\sigma_{\mathrm{x}}^{2} \times \sigma_{\mathrm{y}}^{2}}} .
\end{aligned}
$$

Where: $\sigma^{2}$ is the additive genotypic variance, $\sigma^{2} p$ the phenotypic variance and $\mu$ the mean value of the character; cov $(\mathrm{x}, \mathrm{y})$ is the covariance between 2 characters $\mathrm{x}$ and $\mathrm{y} ; \sigma^{2} \mathrm{x}$ is the variance of the character $\mathrm{x}$ and $\sigma^{2} \mathrm{y}$ the variance of the character $\mathrm{y}$.

\section{Results}

\section{Genotypic and phenotypic coefficients of variation}

For all the traits, the phenotypic coefficients of variation (PCV) were higher than the genotypic coefficients of variation (GCV) with relatively small gaps, lower than $10 \%$. For all vegetative growth characteristics, GVC were moderate with values ranging from $18.26 \%$ for the diameter of the petiole to $33.72 \%$ for branching index. PCV were also moderate and differed from $21.87 \%$ for the diameter of the petiole to $37.97 \%$ for branching index. GCV and PCV, on the other hand, were high for all yield related traits with values greater than $40 \%$, except for the number of stamens which had a low GVC of $7.80 \%$ and a moderate PVC of $11.03 \%$ (Table 3). 
Table 3. Genetic parameters of the 15 agromorphological traits scored for parental accessions and their interspecific F1 hybrid progenies.

\begin{tabular}{llllllll}
\hline \multicolumn{1}{l}{ Traits } & $\boldsymbol{\sigma}^{\mathbf{2}} \mathbf{a}$ & $\mathbf{\sigma}^{\mathbf{2}}$ & $\boldsymbol{\mu}$ & $\mathbf{C G V}(\%)$ & $\mathbf{C P V}(\%)$ & $\begin{array}{l}\text { Gap (PCV- } \\
\text { GCV) (\%) }\end{array}$ & $\mathbf{h}^{2} \pm \mathbf{S E}$ \\
\hline Vegetative growth & & & & & & & \\
PLHE & 439.15 & 566.42 & 88.33 & 23.72 & 26.94 & 3.22 & $0.78 \pm 0.02$ \\
PLWI & 835.64 & 1054.75 & 136.16 & 21.23 & 23.85 & 2.62 & $0.79 \pm 0.02$ \\
RAM & 5.97 & 7.57 & 7.25 & 33.72 & 37.97 & 4.25 & $0.79 \pm 0.02$ \\
LBLE & 22.68 & 28.46 & 23.59 & 20.19 & 22.62 & 2.43 & $0.80 \pm 0.02$ \\
LBWI & 11.64 & 16.24 & 17.64 & 19.35 & 22.85 & 3.5 & $0.72 \pm 0.03$ \\
PELE & 5.12 & 8.07 & 8.26 & 27.41 & 34.41 & 7 & $0.63 \pm 0.04$ \\
PEDI & 0.85 & 1.22 & 5.05 & 18.26 & 21.87 & 3.61 & $0.70 \pm 0.04$ \\
\hline Yield related & & & & & & & \\
NFLIN & 3.44 & 4.49 & 4.51 & 41.12 & 46.98 & 5.86 & $0.77 \pm 0.03$ \\
NBST & 0.18 & 0.36 & 5.44 & 7.8 & 11.03 & 3.23 & $0.50 \pm 0.04$ \\
FRLE & 19.02 & 23.68 & 6.23 & 70 & 78.11 & 8.11 & $0.80 \pm 0.03$ \\
FRWI & 3.17 & 3.28 & 4.23 & 42.09 & 42.82 & 0.73 & $0.97 \pm 0.01$ \\
FRPL & 2.77 & 2.89 & 3.5 & 47.62 & 48.64 & 1.02 & $0.96 \pm 0.01$ \\
FRPD & 7.94 & 10.58 & 6.61 & 42.61 & 49.19 & 6.58 & $0.75 \pm 0.04$ \\
NFRIN & 0.46 & 0.65 & 1.38 & 49.3 & 58.61 & 9.31 & $0.71 \pm 0.04$ \\
FRWE & 4177.32 & 4344.91 & 72.02 & 89.74 & 91.52 & 1.78 & $0.96 \pm 0.01$ \\
\hline
\end{tabular}

$\sigma^{2}$ : additive genetic variance, $\sigma^{2}$ : phenotypic variance, $\mu$ : mean value of the trait, GCV: genotypic coefficient of variation, PCV: phenotypic coefficient of variation, $h^{2}$ : Narrow-sens heritability, SE: standard error. Plant Height (PLHE), Plant Canopy Width (PLWI), Ramification index (RAM), Leaf Blade Length (LBLE), Leaf Blade Width (LBWI), Petiole Length (PELE), Petiole Diameter (PEDI), Number of Flowers/Inflorescence (NFLIN), Number of Stamens (NBST), Fruit Length (FRLE), Fruit Width (FRWI), Fruit Pedicel Length (FRPL), Fruit Pedicel Diameter (FRPD), Number of Fruits/Infructescence (NFRIN), Fruit Weight (FRWE).

\section{Narrow sense heritability}

The heritability of all the 15 agro-morphological characters was moderate to high. Heritability of vegetative growth characteristics ranged from 0.63 to 0.80 and that of yield related traits ranged from 0.50 to 0.97 (Table 3).

\section{Genotypic and phenotypic coefficients of correlation}

Except to the ramification index which was negatively correlated with the rest of the vegetative growth traits, genotypic $\left(r_{a}\right)$ and phenotypic $\left(r_{p}\right)$ coefficients of correlation between architectural characters (height and width of the plant) and characteristics of the leaves (length and width of the blade, length and diameter of the petiole) were either high, moderate and positive. In general, the genotypic and phenotypic coefficients of correlation between yield related traits were high or moderate and negative (Table 4 ).

The genotypic and phenotypic coefficients of correlations between vegetative growth characteristics and yield related traits ranged from low to medium. The height of the plant has low phenotypic and genotypic correlations with the number of flowers per inflorescence, the number of stamens per flower, and the number of fruits per infructescence. It was also weakly correlated with the characteristics of the fruit. Branching index was negatively correlated with all the yield related traits except to the number of flowers per inflorescence and the number of stamens per flower. All the other vegetative growth characteristics were positively correlated with yield related traits except to the number of flowers per inflorescence and the number of fruits per infructescence.

On average, positive genotypic coefficients of correlation were observed between leaf petiole length (PELE) and fruit length $\left(\mathrm{r}_{\mathrm{a}}=0.63\right)$, number of stamens per flower $\left(r_{a}=0.56\right)$, fruit weight $\left(r_{a}=0.56\right)$, fruit pedicel length $\left(r_{a}=0.53\right)$ and fruit pedicel diameter $\left(\mathrm{r}_{\mathrm{a}}=0.52\right)$. A positive genotypic coefficient of correlation was also observed between PEDI and FRLE $\left(\mathrm{r}_{\mathrm{a}}=0.52\right)$ (Table 4). 


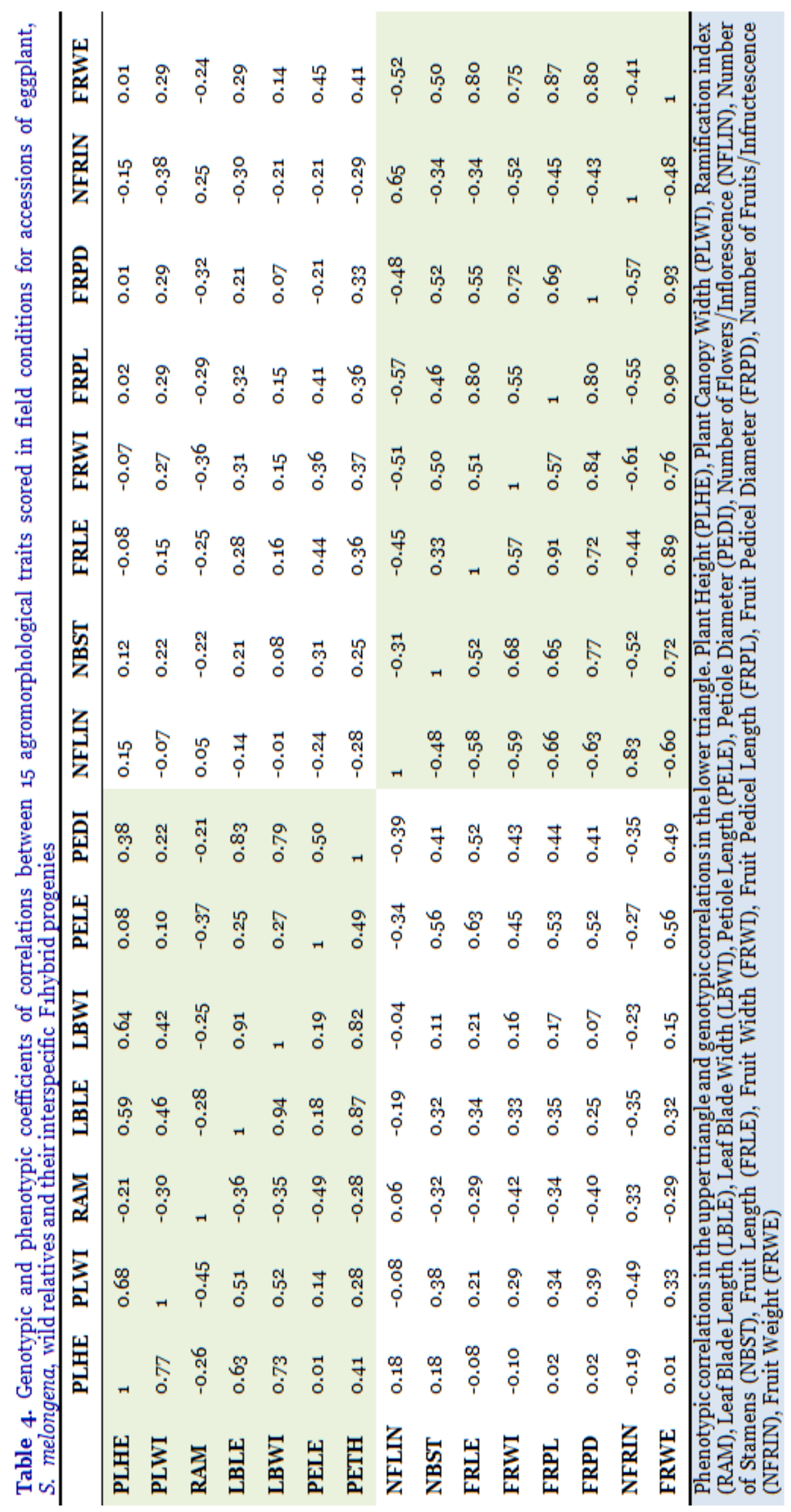




\section{Discussion}

For all the agromorphological characteristics, phenotypic coefficients of variation (PCV) were higher than genotypic coefficients of variation (GCV). However, the gaps between PCV and GCV were small and reflect a relatively weak influence of environmental factors on the expression of the characters (Sawadogo et al., 2015). Dispersion parameters such as the phenotypic coefficient of variation (PVC) provide insights into the level of variability in phenotypic performances of different accessions, but do not indicate the inheritable and non-inheritable parts of that variability (Govindaraj et al., 2011). Indeed, the selection process is all the more effective as the heritability $\left(h^{2}\right)$ of the characters is high and, combination of the genotypic coefficient of variation (GCV) with the heritability provides best information for the choice of the parents to be crossed in order to obtain the ideotype sought by the breeder (Rosmaina et al., 2016).

The small gaps between GCV and PCV were corroborated by high values of narrow sense heritability, ranging from 0.50 to 0.97 . These data indicate important contributions of genes with additive effects in the expression of the characters (Bandi et al., 2018). As reported by Yadeta et al. (2011) for chilli pepper, Capsicum annuum, the high values of narrow sense heritability also suggest that eggplant breeding based on phenotypic data would be very effective. Similar results have been reported for garden eggplant, Solanum gilo Raddi (Danquah and Ofori, 2012), african eggplant, S. aethiopicum (Sawadogo et al., 2016) and eggplant, S. melongena (Rajib et al., 2011; Apkan et al., 2016; Yadav et al., 2016; Jirankali et al., 2019).

Taking into account narrow sens heritability of different traits and their genotypic $\left(\mathrm{r}_{\mathrm{a}}\right)$ and phenotypic $\left(r_{p}\right)$ correlations also allows effective prediction of genetic gains, ie the expected effects of selection (Rosmaina et al., 2016). Correlation data are used to estimate phenotypic values of other characters when selection is applied to a given character (Kouassi et al., 2009). Except to branching index, genotypic and phenotypic correlations were high and positive between vegetative growth characteristics. Thus, if the selection is applied to a trait such as plant height, it will positively affect the other vegetative growth characteristics except to branching index that will be reduced. Concerning yield related traits, if selection is applied, for example, in order to increase the weight of the fruit, the values of the other traits will increase, but the number of flowers per inflorescence and consequently the number of fruits per infructescence will be reduced. Correlations between vegetative growth characteristics and yield related traits were generally moderate and positive. Therefore, phenotypic selection for enhancement of vegetative growth will not negatively affect yield related traits. Genotypic and phenotypic correlations between two given traits, were generally of the same type, that is, negative or positive, and of the same magnitude. However, phenotypic correlations were relatively lower. These data also show that the expression of the characters is essentially under genetic control.

\section{Conclusion}

To our knowledge, this study has provided, for the first time, genetic parameters for agromorphological traits of eggplant, computed based on pedigree information in a plant material comprising accessions of eggplant, wild relatives and their hybrid progenies. The obtained data are therefore assumed to give a reliable insight on heritability and correlations of different vegetative growth and yield related traits. These genetic parameters should be useful in breeding programme aiming to transfer some traits of wild relatives to eggplant or to combine traits of different eggplant accessions in one genotype.

\section{Acknowledgement}

This work was undertaken as part of the initiative "Adapting Agriculture to Climate Change: Collecting, Protecting and Preparing Crop Wild Relatives", which is supported by the Government of Norway. The project is managed by the Global Crop Diversity Trust with the Millennium Seed Bank of the Royal Botanic Gardens, Kew and implemented in partnership with national and international gene banks and plant breeding institutes around the world. For further information, see the project website: http://www.cwrdiversity.org/. 


\section{Conflict of interest statement}

Authors declare that they have no conflict of interest.

\section{References}

Akpan, N. M., Ogbonna, P. E., Onyia, V. N., Okechukwu, E. C., Atugwu, I. A., 2016. Variability studies on ten genotypes of eggplant for growth and yield performance in south eastern Nigeria. J. Anim. Plant Sci. 26(4), 1034-1041.

Bandi, H. R. K., Rao, K. N., Krishna, K. V., Srinivasulu, K., 2018. Variability, heritability and genetic advance for quantitative characters in rice fallow blackgram [Vigna mungo (L.) Hepper]. Int. J. Curr. Microbiol. App. Sci. 7(2), 171-176.

Cericola, F., Portis, E., Toppino, L., Barchi, L., Acciarri, N., Ciriaci, T., Sala, T., Rotino, G. L., Lanteri, S., 2013. The population structure and diversity of eggplant from Asia and the Mediterranean basin. PLoS ONE 8, 73702.

Daunay, M. C., Hazra, P., 2012. Eggplant. In: Handbook of Vegetables (Eds.: Peter, K. V., Hazra, P.). Studium Press, Houston, TX, pp.257-322.

Divya, A., Sharma, A. K., 2019. Genetic variability studies for yield and quality parameters in Brinjal (Solanum melongena L.). J. Pharmacogn. Phytochem. 7(5), 2494-2496.

Fasoula, V. A., Fasoula, D. A., 2002. Principles underlying genetic improvement for high and stable crop yield potential. Field Crops Res. 75, 191-209.

Danquah, J. A., Ofori, K., 2012. Variation and correlation among agronomic traits in 10 accesssions of garden egg plant (Solanum gilo Raddi) in Ghana. Int. J. Sci. Nat. 3(2), 373379.

Denton, O. A., Nwangburuka, C. C., 2011. Heritability, genetic advance and character association in six yield related characters of Solanum anguivi. Asian J. Agric. Res. 5, 201207.

Govindaraj, M., Selvi, B., Rajarathinam, S., Sumathi, P., 2011. Genetic variability and heritability of grain yield components and grain mineral concentration in India's pearl millet (Pennisetum glaucum (L.) R. Br.) accessions. Afr. J. Food Agric. Nutr. Develop. 11(3), 4758-4771.
Gramazio, P., Prohens, J., Plazas, M., Mangino, G., Herraiz, F. J., Vilanova, S., 2017. Development and genetic characterization of advanced backcross materials and an introgression line population of Solanum incanum in a $S$. melongena background. Front. Plant Sci. 8, 1477.

Groeneveld, E., Kovâc, M., Mielenz, N., 2010. VCE User's Guide and Reference Manual, Version 6.0. 125 p. Institute of Farm Animal Genetics, Neustadt, Germany.

Hurtado, M., Vilanova, S., Gramazio, P., Plazas, M., Andújar, I., 2015. Increasing the genetic base of modern cultivars of eggplant of the semilong black type. Bull. UASVM Horticult. $72(2), 281-287$.

IBPGR (International Board of Plants Genetics Resources), 1990. Descripteur pour l'aubergine. 23p.

Jirankali, J. P., Reddy, N., Gangaprasad, S., Manohara, S. N., 2019. Genetic variability for quantitative and qualitative characters in brinjal (Solanum melongena L.). Int. J. Curr. Microbiol. App. Sci. 8(3), 476-484.

Kouassi, A. B., Durel, C.-E., Costa, F., Tartarini, S., Van De Wag, E., Evans, K., FernandezFernandez, F., Govan, C., Boudichevskaja, A., Dunemann, F., Antofie, A., Lateur, M., Stankiewicz-Kosyl, M., Soska, A., Tomola, K., Lewandowski, M., Rutkovski, K., Zurawicz, E., Guerra, W., Laurens, F., 2009. Estimation of genetic parameters and prediction of breeding values for apple fruit quality traits using pedigreed plant material in Europe. Tree Genet. Genom. 5(4), 659- 672.

Kouassi, B., Prohens, J., Gramazio, P., Kouassi, A. B., Vilanova, S., Galán-Ávila, A., Herraiz, F. J., Kouassi, A., Seguí-Simarro, J. M., Plazas, M., 2016. Development of backcross generations and new interspecific hybrid combinations for introgression breeding in eggplant (Solanum melongena). Sci. Hortic. 213, 199-207.

Kruuk, L. E. B., 2004. Estimating genetic parameters in natural populations using the 'animal model'. Philos. Trans. Royal Soc. B (Lond.) 359, 873, 890.

Meyer, R. S., Karol, K. G., Little, D. P., Nee, M. H., Litt, A., 2012. Phylogeographic relationships among Asian eggplants and new perspectives on eggplant domestication. Mol. Phylogen. Evol. 63, 685-701.

Mrode, R. A., 2005. Linear Models for the Prediction of Animal Breeding Values. 2 ${ }^{\text {nd }}$ 
Edn. CABI Publ., Wallingford, 344p.

Muñoz-Falcón, J. E., Prohens, J., Vilanova, S., Nuez, F., 2009. Diversity in commercial varieties and landraces of black eggplants and implications for broadening the breeder's gene pool. Ann. Appl. Biol. 154, 453-465.

Nand, N., Kumar, R., Akhtar, S., Adarsh, A., 2018. Inter relationship between yield and its attributing traits and variability studies in eggplant for future breeding programme. Bull. Environ. Pharmacol. Life Sci. 7(2), 56-62.

Patel, V. K., Singh, U., Goswami, A., Tiwari, S. K., Singh, M., 2017. Genetic variability, interrelationship and path analysis for yield attributes in eggplant. Environ. Ecol. 35, 877880.

Patterson, H. D., Thompson, R., 1971. Recovery of inter-block information when block sizes are unequal. Biometrika 58, 545-554.

Plazas, M., Vilanova, S., Gramazio, P., RodriguezBurruezo, A., Fita, A., Herraiz, F. J., Ranil, R., Fonseka, R., Niran, L., Fonseka, H., Kouassi, B., Kouassi, A. B., Kouassi, A., Prohens, J., 2016. Interspecific hybridization between eggplant and wild relatives from different genepools. J. Amer. Soc. Hort. Sci. 141(1), 3444.

Rajib, R., Souri, R., Jagatpati, T., 2011. Estimation of heritable components of variation and character selection in eggplant (Solanum melongena L.) for mutation breeding program. Cont. J. Biol. Sci. 4(2), 31-36.

Rosmaina, Syafrudin, Hasrol, Yanti, F., Juliyanti, Zulfahmi, 2016. Estimation of variability, heritability and genetic advance among local chili pepper genotypes cultivated in peat lands. Bulg. J. Agric. Sci. 22(3), 431-436.

Sawadogo, B., Bationo-Kando, P., Sawadogo, N., Kiebre, Z., Kiebre, M., Nanema, K. R., Traore, R. E., Sawadogo, M., Zongo, J. D., 2016. Variation, correlation and heritability of interest characters for selection of african eggplant. Afr. Crop Sci. J. 24(2), 213-221.

Sumathi, P., Sumanth, M., Veerabadhiran, P., 2010. Genetic variability for different biometrical traits in pearl millet genotypes (Pennisetum glaucum LR BR.), Elec. J. Plant Breed. 1(4), 437-440.

Sawadogo, N., Nanema, R.., Bationo-Kando, P., Traore, R. E., Nebie, B., Tiama, D., Sawadogo, M., Zongo, J.-D., 2015. Évaluation de la diversité génétique des sorghos à grains sucrés (Sorghum bicolor (L.) Moench) du Nord du Burkina Faso. J. Appl. Biosci. 84, 7654-7664.

Thompson, R., 2008. Estimation of quantitative genetic parameters. Proc. Royal Soc. B: Biol. Sci. 275 (1635), 679-686.

Tirkey, M., Saravana, S., Pushpa, L., 2018. Studies on variability, heritability and genetic advance for yield and its attributes in brinjal (Solanum melongena L.). J. Pharmacogn. Phytochem. 1, 1181-1183.

Verma, P., Kushwaha, M. L., Panchbhaiya, A., 2018. Studies on variability, heritability and genetic advance for yield attributing traits in brinjal (Solanum melongena L.) for two different seasons. Int. J. Curr. Microbiol. App. Sci. 7(9), 1543-1552.

Vilanova, S., Manzur, J. P., Prohens, J., 2012. Development and characterization of genomic simple sequence repeat markers in eggplant and their application to the study of diversity and relationships in a collection of different cultivar types and origins. Mol. Breed. 30, 647-66o.

Vorontsova, M. S., Stern, S., Bohs, L., Knapp, S., 2013. African spiny Solanum (subgenus Leptostemonum, Solanaceae): A thorny phylogenetic tangle. Bot. J. Linn. Soc. 173, 176-193.

Yadav, N., Dhankar, S. K., Chandanshive, A. V., Kumar, V., 2016. Studies on variability, heritability and genetic advance in brinjal (Solanum melongena L.). Bioscan 11(4), 3001-3005 (Supplement on Genetics and Plant Breeding).

Yadeta, B., Belew, D., Gebreselassie, W., Marame, F., 2011. Variability, heritability and genetic advance in hot pepper (C. annuum L.) genotypes in West Shoa Ethiopia. Amer.-Eur. J. Agric. Environ. Sci. 10, 587-592.

\section{How to cite this article:}

Kouassi, A. B., Kouassi, K. B. A., Alla N. O., Kouassi, A., N’guetta, A. S.-P., 2019. Phenotypic and genotypic variability, heritability and correlation estimates for agro-morphological characteristics of eggplant (Solanum melongena) in Côte d'Ivoire. Int. J. Curr. Res. Biosci. Plant Biol. 6(9), 15-23.

doi: https://doi.org/10.20546/ijcrbp.2019.609.003 